TURIZAM

Volume 19, Issue 4 155-164 (2015)

ORIGINAL SCIENTIFIC PAPER

\title{
Traditional Sailing Ships as Indigenous Dalmatian Nautical Product
}

\author{
Srećko Favro* \\ Received: October 2014 | Accepted: August 2015
}

\section{Abstract}

Modern tourist movements of the development of selective tourism forms have offered an opportunity to implement the valorisation of Croatian littoral area through the development of nautical tourism in all its forms, cruising included. As opposed to international cruise market, where the main word have cruisers with few hundred to several thousand passengers, a special type of multi-day cruising or excursion cruising along Croatian coast on traditional Croatian sailing ships has significantly developed in the last few years. Wooden sailing ships have a magical power to attract. They won't pass unnoticed regardless a huge competition of new trends in constructing technologically perfect modern mega-yachts and the most sophisticated mega-cruisers. In this paper, several traditional sailing ships will be described. They were primary intended to transport cargo, and today they're renovated with saloons, kitchens, toilets, bathrooms, air-conditioners and satellite TV receivers. Modern usage of this, for Croatian culture, important indigenous product promotes specificities of Croatian maritime and shipbuilding tradition, creates recognition and authenticity of nautical tourism in Croatia and creates also numerous other positive effects such as promotion of middle and small shipbuilding and employment of local inhabitants on islands that at the same time prevents their depopulation. In order to achieve full potential of this form of Croatian nautical offer it is necessary to invest and to motivate main carriers of activities - small ship owners. Besides the need for economic incentives, it is also very important a joint defining of maritime routes for touristic cruising in the way to select ports that, with the state support, would be renovated to accept cruisers. It is also necessary to set a system of planned cruises and berth reservations by a careful selection of favourable locations. This would enable organisation stages and coordination within the ports, and at the same time it would enable a better efficiency and synergy economic effect of all business subjects in the destination. The most important thing within the selected ports is to enable to small cruisers a safe berth and in order to provide the main function of such port it is necessary to construct all required infrastructure (SRNTH, HHI 2006).

An overview of selected ports to organise berths and to offer services to tourists on traditional sailing ships will be given in this paper, as well as several proposed routes for sailing in the Splitsko-Dalmatinska County. Project implementation will use the possibility to develop certain historical ports along the coast and on islands, with all their specific features and customs that if valorised in the right way can become the initiators of a revival of traditional maritime towns.

Keywords: nautical tourism, sailing ships, cruising, touristic port, traditional port, maritime heritage.

\footnotetext{
* Department of National Economy, University of Split, Faculty of Economics, 21000 Split, Croatia, srecko.favro@efst.hr
} 


\section{Introduction}

Considering geographical characteristics and socio-cultural implications, the Mediterranean is one of the most important regions of nautical tourism in the world. The Mediterranean countries have an important place in nautical tourism development. The Mediterranean Sea stands out among other locations of nautical tourism for its well-indented coastline, flora and fauna richness, favourable hydrographical, navigational and climatic conditions, cultural and historical heritage, and numerous tourist towns and ports of nautical tourism. Eastern Adriatic coast is a unique area in the Mediterranean due to its indented coastline. That coast, according to United Nations Convention on the Law of the Sea is defined as an archipelagic coast (Duplančić Leder et al., 2004).

There are two main groups of comparative advantages on the eastern Adriatic coast. The first group includes good location on the Mediterranean that is becoming an important European and world tourist area, as well as favourable conditions of this coastal area. The second group of comparative development factors includes favourable climatic, geomorphologic and other features of the eastern Adriatic coast. The Republic of Croatia is a Mediterranean country situated along the eastern Adriatic coast. In coastal sea area of the Republic of Croatia there are 1,246 islands, islets, rocks, and rocks awash. That puts Croatia in the second place in the Mediterranean for its indented coast, right after Greece. The length of the Croatian coastline is $6,278 \mathrm{~km}$ - land coastline accounts for $1,880 \mathrm{~km}$ and insular coastline accounts for $4,398 \mathrm{~km}$ (Favro, Saganić, 2006).

Modern tourist development of selective forms of tourism enabled the valorisation of this region through the development of nautical tourism in all its forms (yachting, charter, diving, sailing competitions, cruising). Traditionally, from the golden period of the Republic of Dubrovnik, Croatian Adriatic is known for quality sailors and shipbuilders in wood. A special segment of nautical tourism are traditional sailing ships used for cruising such as old trabaccolos used in the past for the transport of sand and similar materials.

During the last twenty years, ship owners have started with intensive reconstruction of old, wooden sailing ships to designate them to transport passengers on one day excursions or multi-day cruise. Intensive development of the fleet, the developed Croatian coast with numerous islands, islets and cliffs, favourable climate during the whole year, numerous cultural and historical monuments, folklore and ports that can accept smaller cruisers are the precondition Croatia disposes of for organisation and development of domestic cruising. (Matković, Pranić, 2009).

Systematic development of nautical tourism is worked out with the Study and Strategy of nautical tourism in which a significant part has cruising with traditional sailing ships through the reconstruction of the fleet and development of port infrastructure (Favro, Glamuzina 2005). This indicates the fact that the importance to preserve this valuable national heritage has been acknowledged with the aim to estimate the islands' archipelago and further development of nautical tourism, with an emphasis on sustainable development (Study of development of nautical tourism in the Republic of Croatia, 2006).

\section{Historical Development of Maritime Affairs along the Eastern Adriatic Coast}

In fact, from the golden period of the Republic of Dubrovnik, Croatian Adriatic is known for quality sailors and shipbuilders in wood, and Croatian traditional sailing ships are the most important heritage of Croatian shipbuilding. 
They were perfected till they didn't get their final shape that assured a greater strength and better seaworthiness. Numerous sailing ships made by busy hands of Croatian kalafats (ship craftsmen), in the so called "era of sailing ships", that lasted from the 16th until the 19th century, were known to be the most beautiful and the most resistant sailing ships. Official data show that there were 1230 sailing ships for long and big coastal sailings on the Adriatic (from Trieste to Boka) in 1852. In 1910, there were only four of them, and in 1922 the last remaining sailing ship for long sailings sank.

Primary purpose of sailing ships constructed in the area of Eastern Adriatic Coast was to transport raw materials between nearby islands and settlements on the mainland, and later to transport people. Although it is known that numerous exemplars were built along the coast, from today's Istria, Zadar up to Dubrovnik, still Dubrovnik was the most significant one, i.e. the past Republic of Dubrovnik. Besides for transport, sailing ships were also built in Dubrovnik for war and trade purpose that was of extreme importance in that time.

Dubrovnik's very active maritime life and trade connections are best illustrated in Title VII of the Dubrovnik Statute issued in 1272. It depicts various provisions on maritime pledges, harbour taxes, shipping and commerce societies, ships' crews, shipyard workers, seafarers' duties and wages as well as how much cargo can be loaded on board ship. Defined are ships' measurements and types: lignum, navigium, navis, galea, navicula, barcusius, condura, etc. Dubrovnik shipyards became world known for their caracca and galea ships. Quality built and exceptionally seaworthy, these ships were the most famous merchant sailing vessels of their time. The evidence of rich Croatian maritime and shipping heritage are rarely preserved exemplars of traditional Croatian sailing ships, out of which some of the most important are the Dubrovnik carrack, cog, the Dubrovnik Nava, the Dubrovnik galleon, brazzera, and trabaccolo (Kozličić, 1993).

\section{Traditional sailing ships}

Croatia has always been known as a great maritime force. Its sailing ships have taken part in wars, connected islands with mainland, transported gravel and food, and were also known for their beauty. There are several types of sailing ships and each of them has its historical representatives (Kozličić, 1993). There are only a few of them used in modern tourism, and they are trabaccolo, carrack, schooner, bark and logger.

\begin{tabular}{|l|}
\hline \multicolumn{2}{|l|}{ GAETA } \\
\hline - Length 6-8 meters \\
\hline - Width 2-3 meters \\
\hline - Height 1-1,30 meters \\
\hline - 2 meadweight 5-20 tons \\
\hline BRAZZERA of the crew \\
\hline - Length 7-12 meters \\
\hline - Width 3-4 meters \\
\hline - Height 1,50-2 meters \\
\hline - Deadweight $10-40$ tons \\
\hline - 2 members of the crew \\
\hline
\end{tabular}




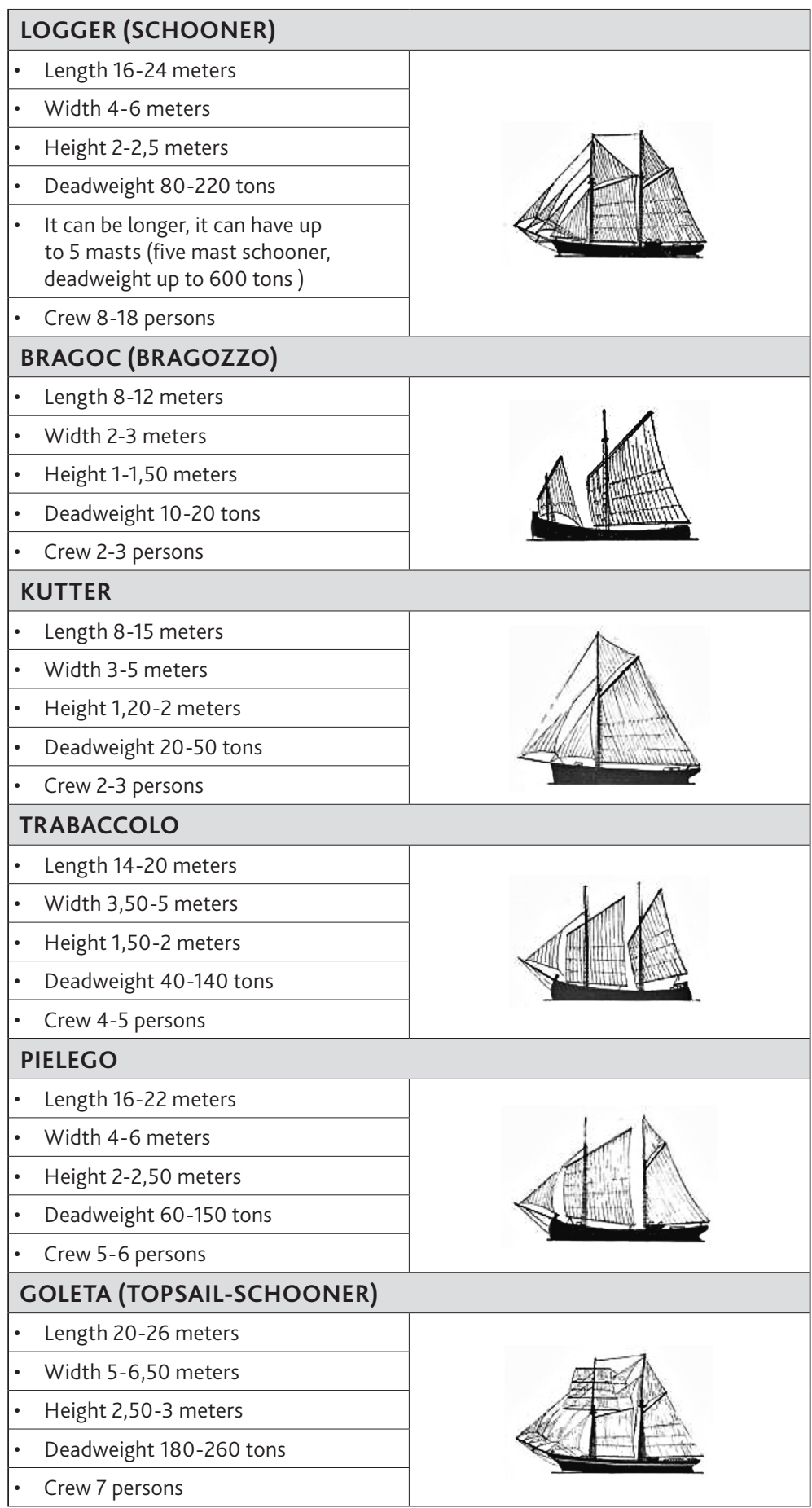






Source: Kozličić, 1993. 


\section{Cruising on Traditional Sailing Ships}

The idea to redirect families of navigators and their cargo sailing ships to receive guests and to cruise exists from the 6 os of the past century. Peter Martinek launched the project. Martinek was a German, more precisely a Croatian German from Srijem who, as many Volksdeutsche, had to leave his home and move to Germany after the World War II. The adaptation of sailing ships started at his initiative. Cabins were made out of plywood, field-beds were put in and barrels were used for showering.

In 1964, Martinek and his associates distribute leaflets in front of church in Stuttgart and nearby places. In these leaflets, he invites people "on pirate journeys across the county of thousand islands". Unfortunately, he didn't live to see his dream come true - more than 10000 guests from Germany who came to Croatia for cruising aboard old sailing ships during one season.

Selimir Ognjenović, who is the owner of the company I.D. Riva Tours from Munich, has continued with the business. His company has a fleet of 25 classical motor sailing ships along the Adriatic. As he says, today motor sailing ships of the fourth generation sail along the Adriatic. These sailing ships are renovated or completely new with iron hull, bigger cabins, toilets, bathrooms, air-conditioners and LCD TVs, and larger area for a smaller number of passengers.

The number of German guests has surpassed the number of 10000 guests a long time ago. Tourists like relaxed cruising aboard sailing ships that don't rush because their speed is between 7 and 12 nautical miles per hour. Approximately 120 classical motor sailing ships intended for pleasure while sailing are sailing along the Croatian Adriatic.

Today, Katarina line is the most significant agency that makes the booking of traditional sailing ships. The Agency has made contracts with ships that are categorized in 4 categories:

1. DELUXE CATEGORY

2. A+ CATEGORY

3. A CATEGORY

4. B CATEGORY

During the boarding of passengers, employees of the agency come to every ship and get the passengers acquainted with rules aboard, warn them about some things and possible problems they could encounter due to their inattention. Employees also inform passengers on breakfast, lunch and dinner time. 
Table 1. A common seven days cruising is presented in continuation:

\begin{tabular}{|c|c|}
\hline ROUTES & DESTINATIONS \\
\hline KL 1 & OPATIJA - KRK - RAB - ZADAR - MOLAT - (Ilovik) LOŠINJ - CRES - OPATIJA \\
\hline KL 2 & SPLIT - MAKARSKA - MLJET - DUBROVNIK - TRSTENIK - KORČULA - HVAR - (Bol) SPLIT \\
\hline KL 3 & $\begin{array}{l}\text { SPLIT - OMIŠ/PUČIŠĆA - KORČULA - LASTOVO - Ravnik (Green Cave - Zelena špilja) - KOMIŽA/VIS - Biševo } \\
\text { (Blue Cave - Modra špilja) - STARIGRAD - STOMORSKA - SPLIT }\end{array}$ \\
\hline KL 4 & $\begin{array}{l}\text { SPLIT - ROGOZNICA/PRIMOŠTEN - KRKA WATERFALLS (Skradin or Zlarin) - KORNATI/SALI - ZADAR - VODICE - } \\
\text { TROGIR - SPLIT (departures 18/06/2013, 16/07/2013, 03/09/2013 only on A category ships) }\end{array}$ \\
\hline KL 5 & DUBROVNIK - KORČULA - HVAR - TRSTENIK - MLJET - ŠIPAN - DUBROVNIK \\
\hline KL 6 & $\begin{array}{l}\text { ONE WAY Opatija- Split: OPATIJA-KRK-RAB-ZADAR-KORNATI/VODICE -KRKA WATERFALLS/PRIMOŠTEN- } \\
\text { TROGIR-SPLIT } \\
\text { ONE WAY Split-Opatija: SPLIT-TROGIR-PRIMOŠTEN-KRKA WATERFALLS/VODICE-KORNATI/ZADAR-RAB- } \\
\text { OPATIJA }\end{array}$ \\
\hline KL 7 & $\begin{array}{l}\text { ONE WAY Split-Dubrovnik : SPLIT - MAKARSKA - BRAČ - VIS - HVAR - KORČULA - MLJET - DUBROVNIK } \\
\text { ONE WAY Dubrovnik-Split : DUBROVNIK - MLJET - KORČULA - HVAR - VIS - BRAČ - MAKARSKA - SPLIT }\end{array}$ \\
\hline KL 8 & $\begin{array}{l}\text { ONE WAY Dubrovnik-Opatija: DUBROVNIK/SLANO-KORČULA-SPLIT-ŠIBENIK-ZADAR-RAB- OPATIJA } \\
\text { ONE WAY Opatija-Dubrovnik: OPATIJA/KRK-RAB-ZADAR-ŠIBENIK-SPLIT-KORČULA- DUBROVNIK }\end{array}$ \\
\hline CYCLING & $\begin{array}{l}\text { OPATIJA - CRES - LOŠINJ - DUGI OTOK - PAG - RAB - KRK - OPATIJA } \\
\text { SPLIT - ŠOLTA - BRAČ - HVAR - KORČULA - MLJET - PELJEŠAC \& MAKARSKA - OMIŠ \& SPLIT } \\
\text { (departures for both OPATIJA and SPLIT ) }\end{array}$ \\
\hline WALK \& HIKE & SPLIT - OMIŠ - JELSA(HVAR) - OREBIĆ - POMENA (MLJET) - LASTOVO (Biševo) - KOMIŽA (VIS) - SPLIT \\
\hline
\end{tabular}

Katarine line cruising

\section{Ports for Traditional Sailing Ships}

In accordance with conclusions of the Strategy of nautical tourism development and the Implementation Action Plan in order to achieve full potential of this form of Croatian nautical offer, it is necessary to invest but also to motivate the main subjects and hosts of services. Besides needs for economic incentives (cheaper fuel, incentive for seasonal employment, cheaper berths and shipyards), it is very important to define together maritime routes for touristic cruises in the way to select ports that would be arranged to accept vessels for cruises. It is necessary to set up a system of planned travels and berth reservations (pre-booking) by a careful selection of appropriate location. This would enable the organisation and coordination within marinas and at the same time the possibility of any dissatisfaction of users and participants in cruises aboard traditional sailing ships would be significantly reduced. Within selected ports, it is crucial to enable a secure berth for smaller cruiser. In order to enable the main function of such port, it is necessary to construct all indispensable infrastructures. Among basic are: connections for electricity and water, and among others are: service, reception, market, catering facilities, etc. (Strategy of Nautical Tourism Development in Croatia, 2009).

The more the infrastructure is developed and services richer, the more will tourists-boaters be satisfied, and the demand for this type of cruising would be on the increase. In order for the thought system to be fully successful, it is of high importance collaboration with local tourist boards. It is up to them to organise an additional tourist offer that contains various tourist activities adapted to seasons, educational structure, and purchasing power of a certain group of guests (Implementation Action Plan, HHI 2013). 
The aim is to use the possibility to develop some historical, smaller ports along the coast and on islands that have specific characteristics and customs, and that, if valorised in a proper way, can become initiators of "the revival" of traditional maritime towns.

The following locations have been proposed to be potential ports for traditional sailing ships in the County of Split-Dalmatia:

1. Milna (the Island of Brač)

2. Postira (the Island of Brač)

3. Sumartin (the Island of Brač)

4. Supetar (the Island of Brač)

5. Bol (the Island of Brač)

6. Hvar (the Island of Hvar)

7. Stari Grad (the Island of Hvar)

8. Jelsa (the Island of Hvar)

9. Sućuraj (the Island of Hvar)

10. Križna luka (the Island of Hvar)

11. Maslinica (the Island of Šolta)

12. Rogač (the Island of Šolta)

13. Nečujam (the Island of Šolta)

14. Stomorska (the Island of Šolta)

15. Vis (the Island of Vis)

16. Komiža (the Island of Vis)

17. Makarska

18. Trogir

19. Kaštel Stari

20. Omiš

21. Krilo jesenice

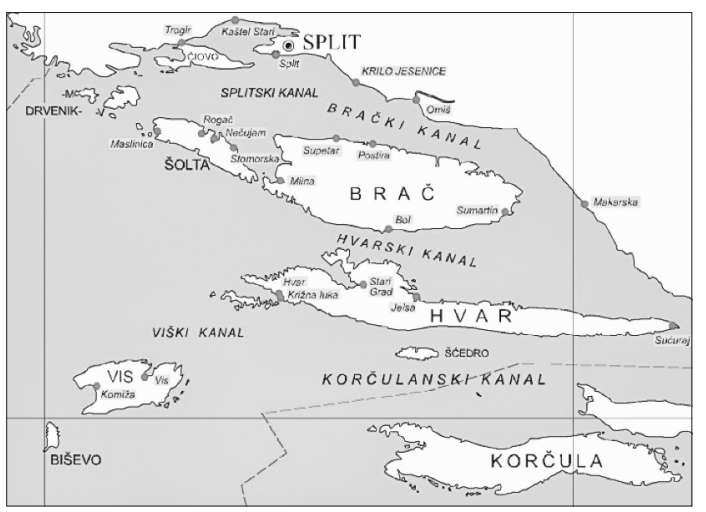

Map 1. Location of ports for traditional sailing ships in the County of Split-Dalmatia

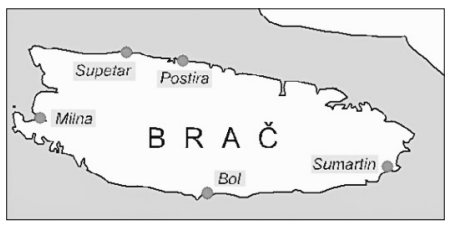

Map 2. Ports for sailing ships on the Island of Brač 


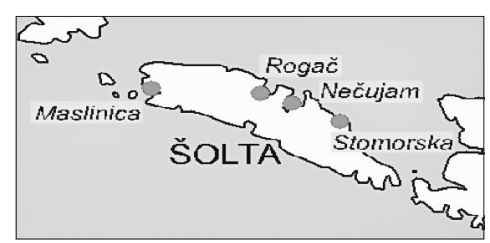

Map 3. Ports on the Island of Šolta

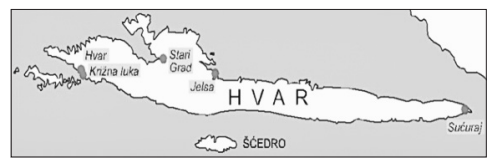

Map 4. Ports on the Island of Hvar

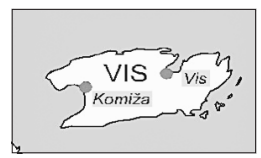

Map 5. Ports on the Island of Vis

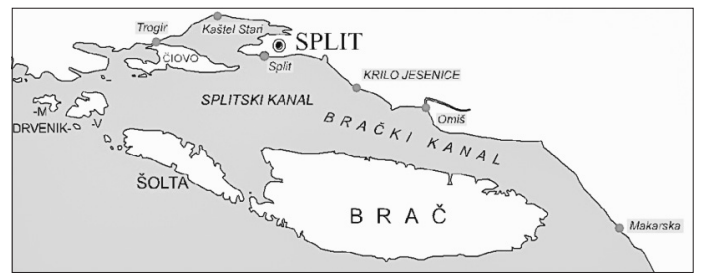

Map 6. Portsfor traditional sailing ships along the coast in the County of Split-Dalmatia

\section{Conclusion}

This paper gives in brief the most important results of the survey carried out for making the Action plan of implementing the Development Strategy of Croatian Nautical Tourism in the area of the County of Split-Dalmatia. The action plan includes the development of marinas, tourist moorings, berths, dry marinas and ports for traditional sailing ships that have been elaborated in this paper. The survey has included the active participation of the local government in order to gather opinions of the local environment. All local authorities have been included and a special emphasis has been put on locations of potential marinas in already existing spatial plan and on potential locations according to professional opinion of constructors.

According to gathered data (remarks and proposals) given by the local community, it is visible that each location thinks about further development of nautical tourism on its area in a specific way and in accordance with its comparative advantages.

Systematic development of this, for Croatian culture important, indigenous product promotes particularities of Croatian maritime and shipping tradition, creates recognition and authenticity of Croatian nautical tourism, and also creates numerous other positive effects such as: fostering development of middle and small shipbuilding, employing local inhabitants on islands, that prevents their depopulation. 


\section{References}

Duplančić, Leder T., Ujević, T., Čala, M. 2004. Coastline Lenghts and Areas of Islands in the Croatian Part of the Adriatic Sea Determined from the Topographic Maps at the Scale of 1:25.00o, Geoadria,

Favro, S., Saganić, I. 2006. Sustainable development of nautical tourism in Croatia., „New Perspectives and Values in World Tourism \& Tourism Management in the Future", Turk-Kazakh International Tourism Conference, Alanya, Turkey, Book 1, 602-620,

Favro, S., Glamuzina, N. 2005. Contemporary problems of Nautical Tourism Development in Croatia, Promet, Portoroz, Trieste, Zagreb, Zilina br.2/2005, ISSN 0353-5320, 107-112,

Kozličić, M.1993. Hrvatsko brodovlje - Croatian Shipping - Le navi croate, trojezična monografija (hrvatski - engleski - talijanski), Književni krug - AGM, Split, Zagreb,

Luković, T. 2007. Nautical Tourism- Definition and Classification, Acta Turistica Nova 1(2).

Matković, J., Pranić, Lj. 2009. The neglected segment of Croatia's tourism: Domestic cruises aboard small vessels - exploratory research, IMSC 2009: 2nd International Marine Science Conference.

Study of Nautical Tourism Development in Croatia (SRNTH), HHI (2006),

Strategy of Nautical Tourism Development in Croatia, Government of the Republic of Croatia, 2009.

Implementation Action Plan for Strategy of Nautical Tourism in Croatia, HHI (2013), Udruga „Latinsko idro", from http://www.latinskoidro.hr/. 